Research Article

\title{
Spread and conditions of Social Innovation Research in Austria in the field of Social Sciences
}

\section{Difusión y condiciones de la Investigación en Innovación Social en Austria en el ámbito de las Ciencias Sociales}

\author{
Klaus Schuch ${ }^{1}$ \\ Centre for Social Innovation, Linke Wienzeile 246, A-1150 Wien, Austria. \\ Correspondence: schuch@zsi.at
}

\begin{abstract}
This paper scrutinises the spread and the conditions of social innovation research in Austria in social sciences. Although the empirical results are inconclusive, social innovation is definitely not a marginal topic in social sciences in Austria. More than $80 \%$ of the responding social scientists deal with social innovation at different levels of intensity. It also seems that social innovation works well for the overall selfrepresentation of the universities. The construct of social entrepreneurship has probably contributed most to anchoring the notion of social innovation in the higher education sector in Austria, especially in teaching. Although some curricula and courses are more confined to traditional business school topics, some transcend the narrow business focus towards sociological and political approaches. The academic embedding of social innovation in Austria, however, is still hampered by structural factors. Our findings show a lack of both tangible and intangible support measures.
\end{abstract}

Keywords: social innovation; Austria; social innovation in Austria; third mission; support measures.

Resumen: Este artículo examina la difusión y las condiciones de la investigación sobre la innovación social en Austria en el ámbito de las ciencias sociales. Los resultados obtenidos muestran que, aunque los datos empíricos no son concluyentes, la innovación social en Austria no es un tema marginal en el contexto de las ciencias sociales. Más del $80 \%$ de los científicos sociales que participaron en la investigación se ocupan de la innovación social en diferentes niveles de intensidad. Asimismo, se revela que la innovación social funciona bien para la autorrepresentación general de las universidades. El concepto de emprendimiento social es el que más ha contribuido a afianzar la noción de innovación social en el sector de la educación superior en Austria, especialmente en la enseñanza. Aunque algunos planes de estudio y cursos se limitan más a los temas tradicionales de las escuelas de negocios, algunos trascienden el estrecho enfoque empresarial hacia enfoques sociológicos y políticos. Sin embargo, la integración académica de la innovación social en Austria sigue viéndose obstaculizada por factores estructurales. Por tanto, los resultados muestran una falta de medidas de apoyo tanto tangibles como intangibles.

Palabras clave: innovación social; Austria; innovación social en Austria; tercera misión; medidas de apoyo.

\footnotetext{
1 The author sincerely thanks Nela Šalamon from the Centre for Social Innovation, Austria, for supporting him in data recording and analysis.
} 


\section{Introduction}

This paper scrutinises the spread and the conditions of conducting social innovation research in Austria in the field of social sciences. It builds on the assumption of an alleged academic reluctance towards social innovation. This assumption is not new, but often raised in the literature (Roessler und Brinkmann, 2020; Howaldt, 2019; Schuch, 2019; Brundenius, 2017). Renault et al. (2017) identify a gap in the literature regarding the role that universities play in promoting social innovation and inclusion in development processes. Howaldt (2019: 40) asserts, "the marginal engagement of research and education facilities is in strong contrast to their essential role as knowledge providers in classical innovation processes (Mowery/Sampay, 2005) and as one actor of the triple helix model." The global mapping of social innovation initiatives during the SI-DRIVE (Social Innovation Driving Force of Social Change) ${ }^{2}$ project empirically confirmed that academia was only marginally involved in social innovation processes (Howaldt, 2019). Cunha and Benneworth (2013) confirm this assessment by stating that community engagement has remained a relatively peripheral activity within universities and that it still operates on a piecemeal basis. However, this is contrasted by increasingly inclusive practices of universities to initiate and implement social innovations - especially involving student engagement - both within the university and in its neighbourhood (Fassi et al., 2020, for example, give an account on this).

To sketch the overall picture how social innovation research is perceived in the academic sector in Austria, we start with an empirical observation about the self-portrayal of Austrian institutions with regard to the occurrence of terms such as "social innovation" and - "social entrepreneurship" on their websites. This first empirical impression is completed by survey results, which show how around 60 senior social scientists in Austria assess the importance of social innovation in the perception of their universities, as a research topic and as a transdisciplinary field of university practice.

We then ask whether social innovation has found its way into university practice through the backdoor of engaging in social entrepreneurship.

Finally, we discuss the lack of institutional and organisational support for social innovation research in the field of academic research in Austria as a reason that negatively affects a stronger academic relationship to the practice field of social innovation.

\section{The spread of social innovation research in Austria in the academic sector based on a web analysis}

Our initial hypothesis is that social innovation research or - in more precise words - the academic embedding of social innovation in social sciences in Austria is still fragile.

Table 1 shows the results of a simple google search of the websites of major Austrian higher education institutions and non-university research organisations for distinct terms such as "social innovation", "soziale Innovation" as the German language expression for it and "social entrepreneurship". The scrutinised terms are under quotes to search for the term exactly as typed by using the 'site:' search function of google. We are aware that this methodology has many shortcomings and calls for a cautious interpretation, not at least because of the non-transparency of the google site search algorithm or the lifetime and architecture of each of the scrutinised websites, which can be very different.

\footnotetext{
2 http://www.si-drive.eu/; accessed on 12 November 2020.
} 
Table 1. Postings of the terms "social innovation", "soziale Innovation" and "social entrepreneurship" at the websites of Austria's major universities and non-university research organisations, ministries and religious and non-religious social welfare organisations.

\begin{tabular}{|c|c|c|c|}
\hline Organisations & $\begin{array}{l}\text { No. of "social } \\
\text { innovation" } \\
\text { postings }\end{array}$ & $\begin{array}{l}\text { No. of "soziale } \\
\text { Innovation" } \\
\text { postings }\end{array}$ & $\begin{array}{l}\text { No. of "social } \\
\text { entrepreneurship" } \\
\text { postings }\end{array}$ \\
\hline University of Vienna & 502 & 399 & 264 \\
\hline Vienna University of Economics and Business & 1,320 & 214 & 3,070 \\
\hline University of Salzburg & 15 & 8 & 16 \\
\hline Karl-Franzens-University of Graz & 128 & 84 & 181 \\
\hline Johannes Kepler University Linz & 382 & 80 & 213 \\
\hline University of Applied Sciences Upper Austria & 120 & 60 & 182 \\
\hline University of Innsbruck & 122 & 188 & 40 \\
\hline ZSI-Centre for Social Innovation & 12,500 & 13,700 & 589 \\
\hline AIT-Austrian Institute of Technology & 209 & 87 & 111 \\
\hline Joanneum Research & 40 & 27 & 32 \\
\hline Salzburg Research & 116 & 96 & 39 \\
\hline $\begin{array}{l}\text { FORBA - Forschungs- und Beratungsstelle } \\
\text { Arbeitswelt }\end{array}$ & 34 & 26 & 2 \\
\hline L\&R Sozialforschung & 7 & 33 & 1 \\
\hline Diakonie & 2 & 28 & 1 \\
\hline Caritas & 4 & 7 & 9 \\
\hline Volkshilfe & 2 & 19 & 2 \\
\hline Arbeit plus & 57 & 47 & 23 \\
\hline Armutskonferenz & 39 & 70 & 49 \\
\hline SENA Social Entrepeneurship Network Austria & 4 & 4 & 105 \\
\hline Federal Ministry of Education, Science and Research & 16 & 88 & 23 \\
\hline $\begin{array}{l}\text { Federal Ministry of Climate Action, Environment, } \\
\text { Energy, Mobility, Innovation and Technology }\end{array}$ & 23 & 41 & 3 \\
\hline $\begin{array}{l}\text { Federal Ministry of Social Affairs, Health, Care and } \\
\text { Consumer Protection }\end{array}$ & 4 & 1,130 & 24 \\
\hline Federal Ministry of Labour, Family and Youth & 5 & 7 & 1 \\
\hline
\end{tabular}

Note: Using the site: operator limits the search results to the ones found in the specified top-level domain. Specifying more parts of the URL narrows the search (see Berry, 2015).

Sources: site:univie.ac.at; site:wu.ac.at; site:uni-salzburg.at; site:uni-graz.at; site:jku.at; site:fh-ooe.at; site:uibk.ac.at; site:zsi.at; site:ait.ac.at; site:joanneum.at; site:salzburgresearch.at; site:forba.at; site:lrsocialresearch.at; site:diakonie.at; site:caritas.at; site:volkshilfe.at; site:arbeitplus.at; site:armutskonferenz.at; site:sena.or.at; site:bmbwf.gv.at; site:bmk.gv.at; site:sozialministerium.at; site:bmafj.gv.at; all accessed on 13 November 2020.

Table 1 clearly shows that one single non-university research institution, ZSI - Centre for Social Innovation, tops all others with regard to the frequency of the searched terms "social innovation" and "soziale Innovation" by a factor of at least 9 and 12 respectively. As regards the term "social entrepreneurship", ZSI tops all but the Vienna University of Economics and Business by a factor of at least 2. While the number of researchers at ZSI is around 45, the University of Vienna in comparison, which is one of the largest universities in Europe with a strong and internationally acknowledged focus on social sciences and humanities ${ }^{3}$, counts around 6,850 researchers (BMBWF, 2019); i.e., 152 times more than ZSI.

\footnotetext{
${ }^{3}$ According to the most recent Times Higher Education Ranking 2021, the University of Vienna is worldwide ranked no. 71 as regards social sciences and on place 34 as regards arts and humanities.
} 
The number of postings of the scrutinised terms "social innovation", "soziale Innovation" and "social entrepreneurship" are in general quite limited. Exceptions, next to ZSI and the University of Vienna, are especially the Vienna University of Economics and Business and the Federal Ministry of Social Affairs, Health, Care and Consumer Protection, where the German term "soziale Innovation" could be identified 1,130 times.

As a side remark, the scrutinised terminology has apparently also found little entry into the self-portrayal of the large Austrian welfare and advocacy organizations Caritas (belonging to the Catholic Church), Diakonie (belonging to the Protestant Church) and Volkshilfe (nonconfessional). Smaller advocacy organisations like "Arbeit plus" or the "Armutskonferenz" have comparably more postings. Maybe terminology and definitions are not as important in the practice of welfare provision or advocacy as in academic science. However, these bleak numbers could also be an indication to reject our assumption that social innovation is a practice field. Anyway, the sober numbers certainly also encourage to reflect more on the perception of social innovation in Austria.

Figure 1. Postings of the terms "social innovation", "soziale Innovation" and "social entrepreneurship" at the websites of Austria's major universities and non-university research organisations (except ZSI)

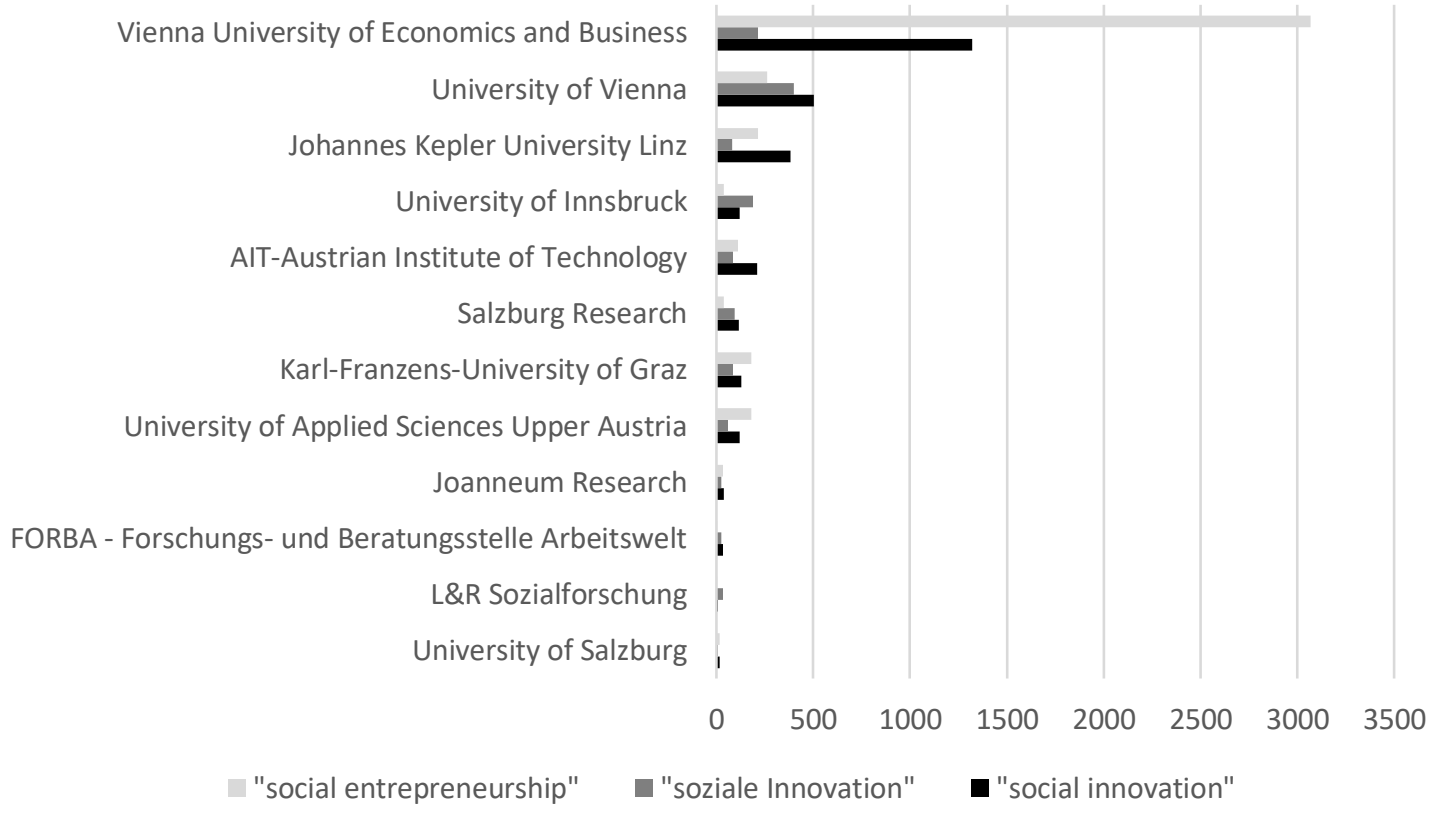

Source: google search (search:) of the following websites between 21 and 23rd October 2020: uni-salzburg.at; www.uni-graz.at/de; www.wu.ac.at/; www.zsi.at; univie.ac.at; www.fh-ooe.at; www.salzburgresearch.at; www.ait.ac.at; www.forba.at; www.lrsocialresearch.at/; www.sozialministerium.at; www.bmafj.gv.at; arbeitplus.at; www.armutskonferenz.at; www.gemse.or.at; diakonie.at; www.caritas.at; /www.bmk.gv.at; www.bmbwf.gv.at; www.jku.at; www.volkshilfe.at; www.joanneum.at; www.uibk.ac.at.

If we exclude ZSI, which obviously has a unique selling proposition within the Austrian social innovation ecosystem, and focus only on higher education and the other non-university research organisations than we can identify from Figure $1^{4}$ some interesting features:

1) The sheer numbers of postings of the catchwords "social innovation", "soziale Innovation" and "social entrepreneurship" at the websites of the most important Austrian higher education institutions and non-university research centres (except ZSI), which have a strong focus on social sciences, is in general quite low. This could be

\footnotetext{
4 The research performing organisations are sorted by the sum of the postings containing "social innovation" and "soziale Innovation" in descending order.
} 
interpreted as a proxy that social innovation is not a priority in the Austrian academic sector.

2) Exceptions to this disillusioning result, which, however, should not be overrated in terms of its explanatory power, are in particular the Vienna University of Economics and Business (WU) and the University of Vienna. While the WU is especially visible as regards the term "social entrepreneurship" with more than 3,000 postings (and in this respect also overshooting ZSI), the entries of the catchwords at the University of Vienna are more balanced.

3) Among the non-university research organisations (except ZSI), AIT is in the lead, closely followed by the much smaller Salzburg Research.

4) From a geographical point of view, it seems that academic engagement in Austria as regards "social innovation" and "social entrepreneurship" is mostly taking place in Vienna (where also ZSI is located), followed by Upper Austria and Innsbruck, and to a lesser extent in Salzburg and Graz.

We then scrutinised the context in which the term "social innovation" appeared on the websites of a few universities (University of Salzburg, University of Graz, Vienna University of Economics and Business, University of Vienna, University of Applied Sciences Upper Austria). Semantic mapping was neither straightforward nor free of overlap. It turned out that the term "social innovation" was most frequently used in connection with "news announcements", "teaching or outreach offers to students and teachers", and in relation to "publications" and "CVs". Mentions related to "research groups/institutes," "references to third parties," or in "strategic documents" were less frequent, as were mentions of specific "social innovation projects".

To balance the one-dimensionality of google search, we also sent a survey to 163 senior social scientists from five Austrian higher education institutions ${ }^{5}$. All of them were either deans or vicedeans of social sciences faculties, heads of social scientific institutes, departments and centres or heads of primarily interdisciplinary research platforms in which social sciences are included. 61 responded to the survey out of which we collected full responses to all first-order questions from 56 respondents. The response rate was slightly above a third and relatively well balanced across the five surveyed higher education institutions.

Table 2. The importance of social innovation in the perception of five Austrian universities, as a research topic and as a transdisciplinary field of university practice.

\begin{tabular}{|c|c|c|c|c|c|}
\hline $\begin{array}{l}\text { Question 1/ } \\
\text { Answer } \\
\text { categories }\end{array}$ & $\begin{array}{l}\text { The current } \\
\text { significance of social } \\
\text { innovation in the self- } \\
\text { image or self- } \\
\text { representation of your } \\
\text { university (overall } \\
\text { level) as a whole in \% }\end{array}$ & $\begin{array}{l}\text { Question 2/ } \\
\text { Answer } \\
\text { categories }\end{array}$ & $\begin{array}{l}\text { Social innovation } \\
\text { as a topic that } \\
\text { your institute or } \\
\text { research platform } \\
\text { deals with in } \\
\text { research in \% }\end{array}$ & $\begin{array}{l}\text { Question 3/ } \\
\text { Answer } \\
\text { categories }\end{array}$ & $\begin{array}{l}\text { Development of } \\
\text { social innovations } \\
\text { in cooperation with } \\
\text { practice partners } \\
\text { over the last } 12 \\
\text { months }\end{array}$ \\
\hline $\begin{array}{l}\text { Social } \\
\text { innovation } \\
\text { has almost } \\
\text { no } \\
\text { significance } \\
\text { as a topic }\end{array}$ & $5 \%$ & Yes, often & $30 \%$ & Yes & $41 \%$ \\
\hline $\begin{array}{l}\text { Social } \\
\text { innovation } \\
\text { is a niche } \\
\text { topic }\end{array}$ & $48 \%$ & $\begin{array}{l}\text { Selectively, but } \\
\text { then mostly as } \\
\text { a central theme }\end{array}$ & $20 \%$ & No & $41 \%$ \\
\hline
\end{tabular}

\footnotetext{
${ }^{5}$ The five higher education institutions together comprise a substantial part of the Austrian university-based social scientific disciplines. The five organisations are the University of Vienna, the Karl-Franzens University in Graz, the Vienna University for Economics and Business, the Paris-Lodron-University Salzburg and the University of Applied Sciences from Upper Austria (with several locations).
} 


\begin{tabular}{|c|c|c|c|c|c|}
\hline $\begin{array}{l}\text { Social } \\
\text { innovation } \\
\text { is an } \\
\text { important } \\
\text { topic }\end{array}$ & $33 \%$ & $\begin{array}{l}\text { Selectively, but } \\
\text { then pre- } \\
\text { dominantly } \\
\text { only as a } \\
\text { marginal topic }\end{array}$ & $34 \%$ & $\begin{array}{l}\text { I do not } \\
\text { know }\end{array}$ & $18 \%$ \\
\hline \multirow[t]{2}{*}{$\begin{array}{l}\text { I do not } \\
\text { know }\end{array}$} & $15 \%$ & $\begin{array}{l}\text { Pretty much } \\
\text { never }\end{array}$ & $11 \%$ & & \\
\hline & & I do not know & $5 \%$ & & \\
\hline Sum & $100 \%$ & Sum & $100 \%$ & Sum & $100 \%$ \\
\hline
\end{tabular}

Note: The following five universities were scrutinised: University of Vienna, the Karl-Franzens University in Graz, the Vienna University for Economics and Business, the Paris-Lodron-University Salzburg and the University of Applied Sciences from Upper Austria.

Source: own survey, $\mathrm{n}$ for all 3 questions is 61 .

As we can see from Table 2, the respondents consider social innovations to be of relatively high importance in university practice. $33 \%$ consider social innovation to be an important topic within the self-understanding respectively self-representation of their university. $48 \%$ consider it a niche topic. Only 5\% responded that social innovation has almost no significance as an overall topic for their universities and $15 \%$ did not know.

Moreover, 30\% regard social innovation as a topic that their institute, research group or research platform often deals with in research. $20 \%$ deal with it selectively, but then mostly as a central theme. $34 \%$ deal with it only marginally and $11 \%$ never. The latter value, which only refers to the consideration of social innovation in social scientific research, is more than double as high than the value of those who responded that social innovation has almost no significance as an overall topic for their universities. Finally, $41 \%$ of the responding social scientists confirmed that their institute respectively research group or platform worked together with practitioners on the development of social innovations within the last 12 months. Just as many denied this question (see Table 2).

Although the results are inconclusive, it can definitely not be said that social innovation is only a marginal topic in the university-based social sciences in Austria. Thus, the survey findings do not seem to coincide with the disillusioning results from google search. More than $80 \%$ of the respondents deal with social innovation research at different levels of intensity. It also seems, that social innovation works well for the overall self-representation of the universities, is a widespread issue in social scientific research in Austria, and is for almost half of the respondents also an object of practical development with practice partners. The latter refers especially to the University of Applied Science of Upper Austria and the Vienna University for Economics and Business, which also can be considered as the two most application-oriented universities within our sample.

After this first candlelight look at how social innovation is perceived by academic institutions in Austria, we were asking if the construct of social entrepreneurship has probably contributed most to anchoring the notion of social innovation in the Austrian higher education sector.

\section{Social entrepreneurship: a stepping stone for the spread of social innovation in Austria's higher education sector or a gatekeeper?}

We hypothesize that the construct of social entrepreneurship has probably contributed most to anchoring the notion of social innovation in the Austrian higher education sector. There is hardly any university of economics and business or higher education business school that does 
not offer a course, an 'academy' or at least some lectures on social entrepreneurship. Social entrepreneurship has become also structurally visible in form of departments and centres. The Vienna University of Economics and Business for example has a 'Social Entrepreneurship Center', which is active in all three pillars of a modern university: education, research and third mission. Another well-known example from Germany is the 'Social Entrepreneurship Academy', a distinct organisation based on the cooperation of universities located in Munich (including the LudwigMaximilians-University Munich, the Technical University of Munich and the Munich University of Applied Sciences). It should be noted, however, that capacity building for social entrepreneurship is also offered by a number of non-university organisations in Austria such as the Impact Hub Vienna ${ }^{6}$ or ZSI, sometimes in cooperation with higher education institutions.

Social entrepreneurship as a tool to promote social innovation has also been strongly encouraged at the European level. Examples for this are the European Social Innovation Competition $^{7}$ (EUSIC) and the Social Innovation Tournament ${ }^{8}$. There were, however, also some European initiatives that focussed more on innovations in the field of social policies, such as the Employment and Social Innovation Programme ${ }^{9}$, or on social innovation in research ${ }^{10}$, but in general the focus on social entrepreneurship prevails at the European level ${ }^{11}$.

Davies (2014) even argued that social entrepreneurship was dominating discussions of social innovation and that the two terms were often discussed synonymously although their essence is not the same. While it is assumed that social innovation transcends sectors and aims for changes at various levels from micro-level to macro-level or even system's level, social entrepreneurship is regarded as limited to market-orientation, business and centred on individual entrepreneurs (Nicholls \& Huybrechts, 2012; Westley \& Antadze, 2010; Phills et al., 2008). For a more in-depth reflection on the relation between social innovation and social entrepreneurship we recommend Davies (2014), who argues that social entrepreneurship partly overlaps with social innovation, but does not entirely fall under it. In Figure 2, Davis (2014) aims to schematically elaborate the different conceptual extensions of social innovation, social entrepreneurship and social enterprise. He shows in the diagram that these partly overlap, but also have their own distinct characteristics.

The question remains how narrowly (i.e., centred only on theories of non-profits and on their commercial activities) social entrepreneurship materialises empirically in educational offers of higher education institutions or if also an extended view, in which also social innovators beyond business (Perrini, 2006) are considered. The answer is ambiguous, at least with a view on Austria. The compulsory optional subject "social business"12 offered by the University of Applied Sciences Burgenland, for instance, rather belongs to the 'narrow' concept. Most of the topics are clearly related to more traditional business school subjects, such as "social economy", "social enterprises", "marketing and fundraising", "social entrepreneurship", and "digital business", but also a course on "international relations and development policies" is offered, that transcends the narrow business focus. On the other hand, the "social economy" BSc course offered by the University of Linz (JKU, 2020) is clearly an example for a 'wider' approach by explicitly

\footnotetext{
6 https://vienna.impacthub.net/; accessed on 22nd December 2020.

7 https://ec.europa.eu/growth/industry/policy/innovation/social/competition_en; accessed on 28 October 2020.

8 https://institute.eib.org/social-innovation-tournament-2/; accessed on 28 October 2020.

9 https://ec.europa.eu/social/main.jsp?langId=en\&catId=1081; accessed on 28 October 2020.

10 https://ec.europa.eu/digital-single-market/en/collective-awareness; accessed on 28 October 2020. The collective awareness platforms supported under Horizon 2020 are a good example for a more technologyoriented approach to social innovation support.

11 https://ec.europa.eu/growth/industry/policy/innovation/social_en; accessed on 28 October 2020, provides a - slightly outdated - overview.

12 https://www.fh-burgenland.at/studieren/bachelor-studiengaenge/bakk-internationalewirtschaftsbeziehungen/lehrveranstaltungen/\#c2807; accessed on 29 October 2020.
} 
integrating societal and political topics in the curriculum, such as sociological theories, history of sociology and social philosophy, and gender studies.

Figure 2. Relationship between social innovation, social entrepreneurship and social enterprise.

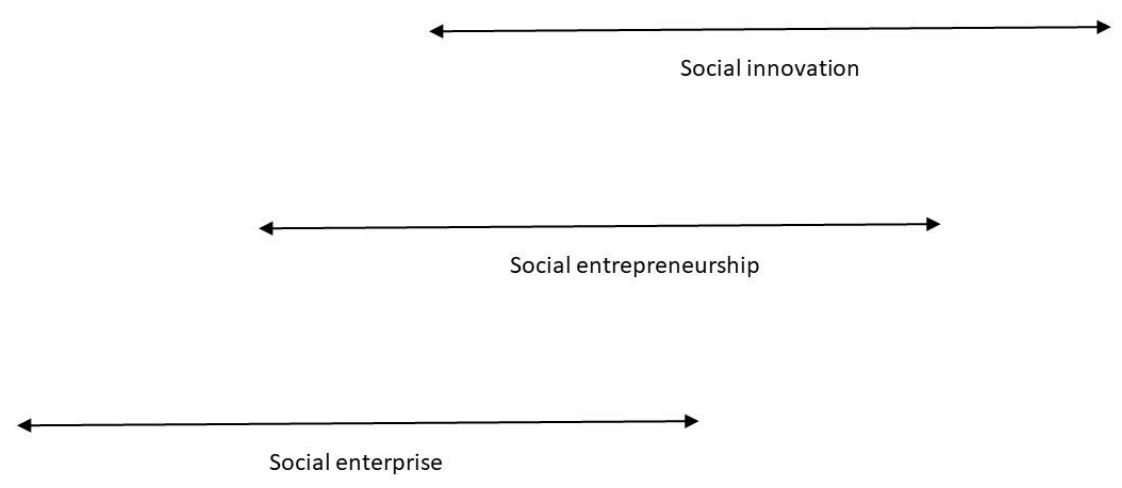

Source: Taken from Davies (2014).

We assume that this ambiguous Austrian situation is not an exception within the European Higher Education Area and that almost every higher educational niche is occupied by remarkable variations that differentiate the educational offers and unique selling propositions of the various higher education institutions. Our conclusion is, thus, to confirm the hypothesis that the construct of social entrepreneurship has probably contributed most to anchoring the notion of social innovation in the higher education sector through the establishment of varied curricula and courses. Some of them are more confined to traditional business school topics, but some transcend the business focus towards sociological and political approaches. Our assessment is at least by tendence supported by the feedback of senior social scientists in Austria. $48 \%(n=56)$ at least tend to agree that social innovation has found its way into university teaching primarily through the topic of social entrepreneurship, while $18 \%$ tend to disagree. $34 \%$ have no opinion on this.

As regards educational offers in higher education institutions we must not forget, however, that universities also offer courses for studying social innovation per se, which also penetrated the higher education sector ${ }^{13}$. In Austria, the first master's program "social innovation" was offered by the Danube University Krems in cooperation with ZSI as a part-time course, but ended after a few years due to a lack of demand. Currently the University of Applied Sciences Upper Austria and the Salzburg University of Applied Sciences offer Master courses in "Management Social Innovation" respectively "Social Innovation". The content of Salzburg's Master's degree on "Social Innovation" is broadly based on four macro modules, within the framework of which the respective professional qualifications are conveyed. They include "Social change and ethics", "Science of Social Innovations", "Fields of action (social innovation)" and "(Innovation) action and methods".

\footnotetext{
${ }^{13}$ To name a few, examples are the Master of Studies in Social Innovation of the Cambridge University, Judge Business School (https://www.jbs.cam.ac.uk/programmes/mst-social-innovation/), the MA in Social Innovation of the University of San Diego (https://www.sandiego.edu/peace/academics/social-innovation/) or the MSc Social Innovation of the Glasgow Caledonian University.
} 
At the international level, we can observe an increasing differentiation as regards social innovation curricula. While the London School of Economics and Political Sciences for instance bridges in its master course conventionally social innovation and entrepreneurship ${ }^{14}$, other interesting connections emerge, such as between social design and sustainable innovation ${ }^{15}$ or between social innovation and sustainable development ${ }^{16}$, just to name a few.

However, despite some inspiring examples of academic 'social innovation' curricula around the globe, the number of social entrepreneurship courses seems to outweigh the number of social innovation courses. While "social entrepreneurship" has been very well received in business schools as a distinct course format, "social innovation" seems to be rather dispersed across different social science courses with different focuses. We wondered whether epistemological reasons related to the broader understood and fuzzy focus of social innovation are to blame for that. However, our question if the concept of social innovation is epistemologically unhelpful for gaining new insights was mostly refused by $62 \%$ of the respondents from social sciences in Austria. $27 \%$ had no opinion on that.

Table 3. Is the concept of social innovation epistemologically unhelpful for gaining new insights? $(\mathrm{n}=56)$.

\begin{tabular}{|c|c|c|c|c|c|c|c|}
\hline $\begin{array}{l}\text { Answer } \\
\text { categories }\end{array}$ & $\begin{array}{l}\text { Univ. of } \\
\text { Applied } \\
\text { Sciences } \\
\text { Upper } \\
\text { Austria }\end{array}$ & $\begin{array}{l}\text { Karl- } \\
\text { Franzens- } \\
\text { University } \\
\text { Graz }\end{array}$ & $\begin{array}{l}\text { Paris- } \\
\text { Lodron- } \\
\text { University } \\
\text { Salzburg }\end{array}$ & $\begin{array}{l}\text { University } \\
\text { of Vienna }\end{array}$ & $\begin{array}{l}\text { Vienna } \\
\text { University } \\
\text { of } \\
\text { Economics } \\
\text { and } \\
\text { Business }\end{array}$ & Total & $\begin{array}{c}\text { Total in } \\
\%\end{array}$ \\
\hline $\begin{array}{l}\text { Do not } \\
\text { agree }\end{array}$ & 1 & 1 & 2 & 3 & 5 & 12 & $21 \%$ \\
\hline $\begin{array}{l}\text { Rather not } \\
\text { agree }\end{array}$ & 3 & 1 & 2 & 8 & 9 & 23 & $41 \%$ \\
\hline $\begin{array}{l}\text { Rather } \\
\text { agree }\end{array}$ & 0 & 0 & 1 & 3 & 1 & 5 & $9 \%$ \\
\hline Agree & 1 & 0 & 0 & 0 & 0 & 0 & $2 \%$ \\
\hline No opinion & 3 & 3 & 1 & 3 & 5 & 15 & $27 \%$ \\
\hline Total & 8 & 5 & 6 & 17 & 20 & 56 & $100 \%$ \\
\hline
\end{tabular}

Source: Authors' elaboration.

In the next session, we show that the academic embedding of social innovation in Austria is also hampered by structural reasons, which have to do with how universities function.

\section{Structural shortcomings at university-level to support social innovations}

In this section we discuss structural problems that make it difficult to deal with social innovation at university level. Our hypothesis is that the existing support structures for social innovation solutions (e.g., in contrast to technical innovation solutions), if they exist at all, do not go far enough in the university structure. We refer here to Brudenius (2017: 43), who claimed that "Not very much is written on the role of social innovation at universities, and vice versa about

\footnotetext{
14 https://www.lse.ac.uk/study-at-lse/Graduate/Degree-programmes-2020/MSc-Social-Innovation-andEntrepreneurship; accessed on 29 October 2020.

15 https://www.lse.ac.uk/study-at-lse/Graduate/Degree-programmes-2020/MSc-Social-Innovation-andEntrepreneurship; accessed on 29 October 2020.

16 https://www.masterstudies.com/Master-in-Social-Innovation-for-Sustainable-

Development/Italy/TSD/\#requestinfo or https://www.masterstudies.com/Master-in-Social-Innovation-for-

Sustainable-Development/Italy/TSD/\#requestinfo; accessed on 29 October 2020.
} 
the role of universities when it comes to social innovation activities" and Howaldt (2019: 37) who argues that "It will be a major challenge for the development of social innovation to ensure a much higher involvement of research and education facilities. In these processes social sciences will be challenged to redefine their functions with regard to innovation".

As already argued in another paper (Schuch, 2019), several structural shortcomings exist why universities do not play a significant role for the co-creation of social innovations in an ideal quadruple helix composition:

1) Social innovations are often bottom-up and straightforward in scope and scale. They are mostly initiated by practitioners in their own field of work and expertise. Financing needs and relational capital needs are usually more pressing, or at least seem so, than knowledge deficits. The most often raised knowledge deficits relate to a segment of business-related disciplines, namely to issues of taxation, marketing and financing. This limits the demand for support from academic knowledge providers to business related issues.

2) The financial precariousness of most social innovations is another demand-side problem. Social innovations often operate in low-cost segments, while the cost structures of universities hardly fit to the tight budgets of social innovators. While 'normal' technology transfer enjoys a high reputation at universities (and especially of funding agencies and R\&I policy-makers), knowledge transfer for social purposes is often perceived as an altruistic free of charge exercise. The limited prospect of acquiring third-party funding reduces the attraction for higher education institutions to deal with it. It also means that the social sciences do not have a lucrative field of activity that would be comparable to those of the technical sciences and engineering.

3) While technological (commercial) innovation is recognised as a potential income source for universities, and thus facilitated by institutionalised support structures such as technology transfer centres, there are only exceptionally material and immaterial professional university structures available for supporting social innovations. Examples are the '6I research model' at the University of Deusto (Caro-Gonzalez, 2019), the "Tellus Innovation Arena" and the "Oulu Think Tank of Science and Society" at the University of Oulu (Tuunainen et al., 2019) or the Knowledge Transfer Centre for SSH in Austria (Russegger, 2019).

4) Social innovations do not count for the performance accountability of universities and their faculty. Thus, they lack promotional quality and significance. Neither social innovations initiated by higher education institutions, nor practices and systems how to monitor, measure and promote their way from universities to society are regularly documented and in the focus of attention of university management (systems).

5) Universities lack the appropriate infrastructure and resources for social innovation, although - together with their students - they could have a large mobilisation effect. Places designed to meet, to exchange, to co-design and prototype social innovations with practitioners are still scarce within the academic infrastructure. The lack of interfaces also means that little is known about specific needs that emerge from the practice field.

6) Despite the fact that SSH scholarship (and also other fields of science) is often committed to do research for the good of society, the interest of researchers is often not oriented towards producing usable results such as social innovations (see the various aspects discussed in Reale et al. 2017; Benneworth, 2015; Brewer, 2013; Nussbaum, 2010).

The findings from our survey confirm that structural shortcomings at university-level to support social innovation exist. We have already shown that around $41 \%$ of the responding senior social scientists from selected Austrian universities were engaged in developing social innovation with practitioners during the last 12 months, which is a remarkable high level. However, only $25 \%$ of the respondents confirmed the existence of support measures to facilitate the cooperation with practitioners as regards the development of social innovations at their universities or 
faculties. 35\% explicitly negated and $40 \%$ did not know. The latter means in practice, that no support structures were accessible for those $40 \%$ of respondents.

Table 4 shows which support measures are available at the five scrutinised Austrian universities which all have a strong social science focus. It is striking that only one of the potential 'support measures' queried is frequently encountered, namely that students can work in courses on the development of social innovation together with practice partners. But $25 \%$ of the respondents stated that this was not possible. However, the overall number of respondents is too small to make any generalisation.

$38 \%$ of the already small number of respondents who were able to report on specific support measures from their university or faculty said that they were encouraged by the university or faculty to work together with practice partners to develop social innovations. $31 \%$ confirmed that the university or faculty management actively forwards requests from practice partners to them. $31 \%$ also confirmed that their work on developing social innovations with practice partners is used by the university or faculty for PR purposes. The other respondents denied this.

All other inquired potential support measures were only very sporadically mentioned. These include in particular

- The lack of university or faculty funds to finance participation of the university's faculty in the development of social innovations.

- The lack of inclusion of social innovation development projects in the performance reporting of universities.

- The lack of a cooperation platform where practice partners can regularly inform about their needs to support social innovations.

- The lack of possibility to participate in the development of social innovations through university-funded research projects ${ }^{17}$.

Table 4. Support measures provided by the university or faculty to work on the development of social innovations with partners from practice $(n=16)$.

\begin{tabular}{|l|l|l|}
\hline Statements & $\begin{array}{l}\text { Yes } \\
(\%)\end{array}$ & $\begin{array}{l}\text { No } \\
(\%)\end{array}$ \\
\hline $\begin{array}{l}\text { A cooperation platform exists where practice partners can regularly report their needs to support } \\
\text { social innovations }\end{array}$ & $19 \%$ & $81 \%$ \\
\hline $\begin{array}{l}\text { A small university or faculty fund through which we can finance our participation in the } \\
\text { development of social innovations exists } \\
\text { We are allowed to work with students in our courses on the development of social innovation } \\
\text { with practice partners }\end{array}$ & $6 \% \%$ & $94 \%$ \\
\hline $\begin{array}{l}\text { We can contribute to the development of social innovations through research projects financed } \\
\text { by the university }\end{array}$ & $25 \%$ \\
\hline $\begin{array}{l}\text { The university/faculty management encourages us to cooperate with practice partners to develop } \\
\text { social innovations }\end{array}$ & $38 \%$ & $75 \%$ \\
\hline $\begin{array}{l}\text { The university or faculty management actively forwards requests from practice partners for the } \\
\text { development of social innovations to us }\end{array}$ & $31 \%$ & $63 \%$ \\
\hline $\begin{array}{l}\text { Our work on the development of social innovations with practice partners is positively } \\
\text { supported by the university in career promotion and performance assessment }\end{array}$ & $69 \%$ \\
\hline $\begin{array}{l}\text { Our work on the development of social innovations with practice partners is used by the } \\
\text { university resp. faculty for PR purposes }\end{array}$ & $94 \%$ \\
\hline $\begin{array}{l}\text { Social innovation development projects with practice partners are considered in our } \\
\text { performance reporting }\end{array}$ & $31 \%$ & $69 \%$ \\
\hline
\end{tabular}

Source: Authors' elaboration.

\footnotetext{
${ }^{17}$ If research projects make this possible at all, then they are usually externally funded projects.
} 
With the exception of one respondent from the Vienna University of Economics and Business, all other respondents who mentioned structural support measures at their university or faculty for social innovations reported that their work on the development of social innovations with partners from practice is not taken into account by the university in career promotion or performance assessment. 59\% of all respondents $(n=56)$ agreed with the statement that as long as contributions to social innovations in career promotion or performance assessment are not equated with contributions to technical-economic innovations, the importance of dealing with social innovations at universities will remain rather marginalized. $26 \%$ did not agree with this statement and the rest had no opinion on that.

These empirical findings do indeed confirm our hypothesis that systematic structural precautions and support measures for social innovation are still little or not at all developed at Austrian higher education institutions. The importance of technical-economic innovation performance is considered to be much higher in the university system than the contribution to social innovation. Although the number of respondents is too small to make robust and reliable statements, it would be worth considering whether the situation at the universities for applied sciences is better than at the 'regular' universities. The feedback from the FH Upper Austria at least points in this direction. This would certainly fit in with the application orientation of the universities for applied sciences.

\section{Conclusions}

First, we have been able to prove empirically, but limited to Austria, that social innovation plays a role in the consciousness of senior social scientists and has also entered research and teaching. Our findings, however, also indicate that, with few exceptions, terms such as "social innovation" or "social entrepreneurship" appear infrequently in the documented self-image of Austrian academic institutions on their homepages. In this respect, the Centre for Social Innovation (ZSI) outperforms all universities with the exception of $\mathrm{WU}$, where social entrepreneurship plays a very important role in the university's self-representation.

Second, we hypothetically assumed that primarily social entrepreneurship found its way into the formal academic field at universities, especially into teaching. Although social entrepreneurship seems to dominate academic courses, it has not necessarily limited social innovation only to its economic dimension. The results of our survey also support that social entrepreneurship has become a door opener for social innovation in the academic world. Thus, we can consider the second hypothesis as largely confirmed, more in an enabling than in a distorting sense as far as the essence of social innovation is concerned.

Thirdly and finally, we put forward the hypothesis that structural and organizational reasons also stand in the way of a further academic breakthrough of social innovation. These include demand-side problems related to the very bottom-up and practical nature of social innovation, but also to a lack of market potential. Moreover, incentive systems and support systems are both lacking to nurture the willingness of social scientists to engage in the development of social innovations with practitioners. The empirical findings from our survey have clearly shown that there is a lack of both tangible and intangible measures that could contribute significantly to anchoring social innovation more firmly in the university sector. Thus, our third hypothesis can be regarded as confirmed.

Our final appeal is therefore directed at science, research and innovation policy as well as the strategic management of universities. A broadly understood third mission of universities beyond the university-industry nexus often exists only in Sunday speeches, but is little structurally operationalized in reality. Our results have shown that social scientists, although of course not all of them, are interested in both the theoretical discussion of social innovation and its practical development but the bridge between universities and social practice must be strengthened by adequate support measures. 
For future research on the perception and take-up of social innovation in academic research and teaching, we would like to see international comparisons based on a uniform scheme of recording and analysis. In particular, further research on the interface between social innovation and academic acceptance should be more attentive to differences between individual disciplines and, among other things, address the question of why the embedding of a more broadly understood scope of social innovation in university teaching lags behind the more narrowly understood 'social entrepreneurship' focus. If epistemological reasons play only a small role in the lagging institutionalisation, then it should be explored whether organisational reasons due to the inter-disciplinary nature of social innovation play a role in this, or whether a lack of a professional profile or other reasons are significant.

\section{References}

Benneworth, P. (2015). Tracing how arts and humanities research translates, circulates and consolidates in society. How have scholars been reacting to diverse impact and public value agendas? Arts and Humanities in Higher Education, 14 (1), 45-60. https://doi.org/10.1177/1474022214533888

Berry, T. U. (2015). Advanced Search Strategies for Google. The Complete Guide to Using Google in Libraries: Research, User Applications, and Networking, 2, 215-222.

BMBWF. (2019). Statistisches Taschenbuch - Hochschulen und Forschung 2019. Bundesministerium für Bildung, Wissenschaft und Forschung.

Brewer, J. (2013). The public value of social sciences. An interpretative essay. Bloomsbury.

Brundenius, C. (2017). Challenges of rising inequalities and the quest for inclusive and sustainable development. In C. Brundenius, B. Göransson \& J. M. Carvalho de Mello (Eds.), Universities, Inclusive Development and Social Innovation (pp. 9-69). Springer.

Caro-Gonzalez, A. (2019). The "6I Research Model": evolution of an innovation institutional STI policy framework at the University of Deusto. fteval Journal for Research and Technology Policy Evaluation, 48, 86-90. http://repository.fteval.at/id/eprint/445

Cunha, J., \& Benneworth, P. (2013). Universities' contributions to social innovation: towards a theoretical framework. EURA Conference 2013, 3-6 July, Enschede, The Netherlands.

Davies, A. (2014). Social Innovation Process and Social Entrepreneurship. In J. Howaldt, A. Butzin, D. Domanski \& C. Kaletka (Eds.), Theoretical Approaches to Social Innovation. Critical Literature Review. A deliverable of the project Social Innovation: Driving Force of Social Change (SI-DRIVE) (pp. 60-78). TU Dortmund, Sozialforschungsstelle.

Fassi, D., Landoni, P., Piredda, F., \& Salvadeo, P. (2020). Universities as Drivers of Social Innovation. Theoretical Overview and Lessons from the "campUS"' Research. Springer.

Howaldt, J. (2019). New pathways to social change - creating impact through social innovation research. fteval Journal for Research and Technology Policy Evaluation, 48, 37-48. http://repository.fteval.at/id/eprint/434

JKU. (2020). Curriculum zum Bachelorstudium Sozialwissenschaften. UK 033/528, https://www.jku.at/fileadmin/gruppen/32/ZUS/Curricula/Bachelor/10_BS_Soziologie_MTB33_230617.pdf; accessed on 12 November 2020.

Mowery, D. C., \& Sampat, B. N. (2005). Universities in National Innovation Systems. In J. Fageberg, D. C. Mowery \& R. R. Nelson (Eds.), The Oxford Handbook of Innovation (pp. 209-239). Oxford University Press.

Nicholls, A., \& Huybrechts, B. (2012). Social Entrepreneurship: Definition, Drivers, and Challenges. In C. Volkmann, K. Torarski \& K. Ernst (Eds.), Social Entrepreneurship and Social Business (pp. 31-48). Springer Gabler.

Nussbaum, M. (2010). Not for Profit. Why democracy needs the humanities. Princeton University Press. 
Perrini, F. (2006). The New Social Entrepreneurship: What Awaits Social Entrepreneurship Ventures? Edward Elgar.

Phills, J. A., Deiglmeier, K., \& Miller, D. T. (2008). Rediscovering Social Innovation. Stanford Social Innovation Review, Fall edition, 35-43.

Reale, E., D. Abramov, K. Canhial, C., Donovan, R., Flecha et al. (2017). A review of literature on evaluating the scientific, social, and political impact of social sciences and humanities research. Research Evaluation, 111. https://doi.org/10.1093/reseval/rvx025

Renault, T. B., Carvalho de Mello, J. M., \& Araújo, F. (2017). Social development as an academic mission of Brazilian universities: public policies and the case of the Federal University of Rio de Janeiro. In: C. Brundenius, B. Göransson, \& J. M. Carvalho de Mello, (Eds.), Universities, Inclusive Development and Social Innovation, (pp. 71-96). Springer.

Russegger, G. (2019). SSHA-driven knowledge transfer within the third mission of universities. fteval Journal for Research and Technology Policy Evaluation, 48, 62-65. http://repository.fteval.at/id/eprint/438

Schuch, K. (2019). The contribution of social sciences and humanities to social innovation. In J. Howaldt, A. Schröder, C. Kaletka \& M. Zirngiebl (Eds.), Atlas of Social Innovation, 2nd Volume: A World of New Practices (pp. 95-98). Oekom Verlag.

Tuunainen, J., Svento, R., Haddington, P., Ojutkangas, K., \& Aalto, S. (2019). The Oulu way of strengthening social impact of SSH sciences: from linear models of impact to productive interactions and beyond. fteval Journal for Research and Technology Policy Evaluation, 48, 86-90. http://repository.fteval.at/id/eprint/442

Westley, F., \& Antadze, N. (2010). Making a difference: strategies for scaling social innovation for greater impact. The Innovation Journal: The Public Sector Innovation Journal, 15(2), 2-19.

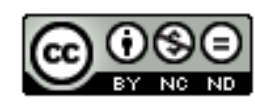

(C) Attribution-NonCommercial-NoDerivatives 4.0 International (CC BY-NC-ND 4.0)

https://creativecommons.org/licenses/by-nc-nd/4.0/ 